Bangladesh J. Pl. Breed. Genet., 20(1) : 13-18, 2007

\title{
COMBING ABILITY OF CMS AND RESTORERS IN RICE (O. sativa L.)
}

\author{
P. S. Biswas, A. W. Julfiquar and M. Wazuddin ${ }^{1}$ \\ Plant Breeding Division \\ Bangladesh Rice Research Institute \\ Gazipur 1701, Bangladesh
}

\begin{abstract}
General and specific combining ability effects were estimated from a 5 line $\times 8$ tester crosses to explore the genetic behavior of CMS and restorers in rice. The variance for GCA and SCA showed predominance of non-additive gene action for all the ten morphophysiological traits. The estimates of GCA effects revealed that none of the parent was general combiner for all the traits in desired direction. Gan46A and BR827R were good general combiners for higher grain yield coupled with earliness, and IR46R and BR168R was good general combiner for grain yield and lateness in maturity. Good x poor general combiners $($ Gan46A $\times$ Gui99R) for grain yield produced the best specific cross for higher grain yield coupled with earliness, longer panicle, panicles/plant, filled grains/panicle and less sterility $(\%)$. Additive $\times$ additive, additive $\times$ dominance and dominance $x$ dominance gene interactions were involved in deriving good specific cross for grain yield.
\end{abstract}

Key words: GCA and SCA effects, gene interaction, CMS, restorer, rice.

\section{INTRODUCTION}

Grain yield of rice is the result of a series of complex morpho-physiological phenomena. There are many factors involved in these processes. Generally, vigor in initial vegetative growth triggers grain yield of rice. Identification of the factors responsible and their genetic control may not only help plant breeders to develop high yielding cultivars but also help agronomists to establish suitable cultural practices. Several approaches have been reported to identify morpho-physiological bases of higher grain yield in rice (Virmani and Edwards 1983, Sunohara et al., 1985, Bashar 2002). But information regarding genetic control of morpho-physiological bases of grain yield is not adequate. To explore such complex processes comprehensive research relating to genetic improvement of morphophysiological traits of rice plants is required (Wazuddin and Julfiquar 2002). Combining ability is one of the powerful tools in identifying the best combiners that may be used in crosses either to exploit heterosis or to accumulate productive genes. It also helps to understand the genetic architecture of various characters that enable the breeder to design effective breeding plan for future improvement of the existing materials. Thus, a study was undertaken to estimate the nature and magnitude of gene action and to explore suitable combination of male sterile and restorer lines with high yield potential.

1 Department of Genetics and Plant Breeding, Bangladesh Agricultural University, Mymensingh 2202, Bangladesh 


\section{MATERIALS AND METHODS}

Forty crosses were made using 5 cytoplasmic-genetic male sterile (CMS) lines and 8 restorer lines following Line $X$ Tester model in 2002. The $F_{1}$ hybrids (40) along with their parents (13) were grown in the experimental field of Bangladesh Rice Research Institute (BRRI) in the Boro season, 2003. Single seedling of thirty day old was transplanted with a spacing of $(20 \times 15) \mathrm{cm}^{2}$ in RCB design with three replications. The unit plot size was $1.8 \mathrm{~m}$ $\times 5$ rows. The crop management was done at par with BRRI recommendation for hybrid rice (BRRI, 2003). Data on leaf area index (LAI), plant height, days to $50 \%$ flowering, panicles/plant, panicle length, filled grains/panicle, spikelet sterility, harvest index, 1000grain weight and grain yield/plant were recorded from ten randomly selected plants from each entry. Analysis of variance (ANOVA) for general combining ability (GCA) and specific combining ability (SCA) effects were estimated according to Kempthorne (1957).

\section{RESULTS AND DISCUSSION}

The analysis of variance (Table 1) showed that the genotypes differed significantly for all the characters. The variances due to parents, hybrids and interaction (P X C) were also significant for all the characters individually. Significant variance due to P X C revealed that there were possibilities of considerable average heterosis among the hybrids. The magnitudes of SCA variances were higher than those of the GCA variance for all the traits. It indicated predominance of non-additive or dominance gene actions in the inheritance of all the growth characters under the study. This observation strongly suggested that exploitation of heterosis from the traits would be feasible deploying the parental lines used in the study. There are many reports (Bobby and Nadaranjan, 1993; Rogbell and Subbaraman, 1997; Lang and Buu, 1993; Sarker et al., 2003) on the preponderance of non-additive gene action in rice. Moreover, several literatures (Salam et al, 1996; Kwak, 1999; Liao-FuMing et al., 2000) on predominance of additive component for different morpho-physiological traits are also available.

Table 1. Analysis of variances for different characters in rice under line $\times$ tester method

\begin{tabular}{|c|c|c|c|c|c|c|c|c|c|c|c|}
\hline $\begin{array}{l}\text { Source of } \\
\text { variation }\end{array}$ & $\mathrm{df}$ & $\begin{array}{c}\text { Leaf } \\
\text { area } \\
\text { index }\end{array}$ & $\begin{array}{c}\text { Plant } \\
\text { height }\end{array}$ & \begin{tabular}{|c|} 
Days to \\
$50 \%$ \\
flowering
\end{tabular} & $\begin{array}{c}\text { Panicles/ } \\
\text { plant }\end{array}$ & $\begin{array}{l}\text { Panicle } \\
\text { length }\end{array}$ & $\begin{array}{l}\text { Filled } \\
\text { grains/ } \\
\text { panicle }\end{array}$ & \begin{tabular}{|l|} 
Spikelet \\
sterility
\end{tabular} & \begin{tabular}{|c|} 
Harvest \\
Index
\end{tabular} & $\begin{array}{c}1000 \\
\text { grain } \\
\text { weight }\end{array}$ & $\begin{array}{l}\text { Grain } \\
\text { yield/ } \\
\text { plant }\end{array}$ \\
\hline$\overline{\text { Replication }}$ & 2 & 2.12 & $102.3 * *$ & $17.55 * *$ & 0.07 & $4.17 * *$ & 112.5 & $214.19 * *$ & 0.002 & 0.39 & 31.17 \\
\hline Genotype & 52 & $5.15 * *$ & $188.8 * *$ & $189.16 * *$ & $5.35 * *$ & $9.37 * *$ & $2467.8 * *$ & $321.12 * *$ & $0.027 * *$ & $15.95 * *$ & $171.2 * *$ \\
\hline Parent (P) & 12 & $4.95 * *$ & $489.6^{* *}$ & $508.06^{* *}$ & $2.42 * *$ & $22.18 * *$ & $2438.9 * *$ & $93.47 * *$ & $0.033 * *$ & $22.23 * *$ & $59.43 * *$ \\
\hline P vs. C & 1 & $33.21 * *$ & $98.2 * *$ & $1078.04 * *$ & $13.62 * *$ & $3.87 *$ & $4069.1 * *$ & $251.14 * *$ & $0.049 * *$ & $10.81^{* *}$ & $855.8 * *$ \\
\hline Crosses (C) & 39 & $4.49 * *$ & $98.6^{* *}$ & $68.25 * *$ & $6.04 * *$ & $5.56 * *$ & $2435.6^{* *}$ & $392.96 * *$ & $0.025 * *$ & $14.14 * *$ & $188^{* *}$ \\
\hline Lines & 4 & 3.45 & $534.58 * *$ & $219.64 * *$ & 5.98 & $23.34 * *$ & 2523.2 & 325.96 & 0.009 & $41.53 * *$ & 267.7 \\
\hline Testers & 7 & 3.39 & $97.89 * *$ & $182.97 * *$ & 8.89 & 2.97 & 2786.1 & $1265.3^{* *}$ & $0.070 * *$ & $43.95^{* *}$ & $355.9^{*}$ \\
\hline Line $\times$ Tester & 28 & $4.91 * *$ & $36.46 * *$ & $17.94 * *$ & $5.34 * *$ & $3.67 * *$ & $2335.5 * *$ & $184.45^{* *}$ & $0.016 * *$ & $2.77 * *$ & $134.6^{* *}$ \\
\hline Error & 104 & 0.54 & 11.9 & 3.03 & 0.97 & 0.86 & 120.8 & 25.33 & 0.003 & 1.04 & 10.79 \\
\hline$\sigma^{2} \mathrm{GCA}$ & & 0.0075 & 1.096 & 0.887 & 0.012 & 0.820 & 1.77 & 3.68 & 0.00016 & 0.201 & 0.942 \\
\hline$\sigma^{2} \mathrm{SCA}$ & & 1.457 & 8.174 & 4.968 & 1.456 & 0.939 & 738.2 & 53.04 & 0.004 & 0.576 & 41.27 \\
\hline$\sigma^{2} \mathrm{GCA} / \sigma^{2} \mathrm{SCA}$ & & 0.005 & 0.134 & 0.179 & 0.008 & 0.873 & 0.002 & 0.069 & 0.039 & 0.349 & 0.023 \\
\hline
\end{tabular}

The sum of squares due to $\mathrm{R}$ lines (tester) were found significant for most of the characters except leaf area index, panicles/plant, panicle length and filled grains/panicle (Table1) indicating their positive contribution towards combining ability. On the other hand, 
the mean sums of squares due to CMS lines were significant for plant height, days to $50 \%$ flowering, panicle length and 1000-grain weight. This indicated that the contribution of lines towards combining ability was poor for most of the yield contributing characters. However, the contribution of either testers or the interactions between line and tester were higher than that of lines to the total variances (Table 2) for all the characters except plant height.

Table 2. Contribution of CMS lines, restorers and their interactions $(A \times R)$ to total variance for different traits in rice

\begin{tabular}{l|c|c|c|c|c|c|c|c|c|c}
\hline $\begin{array}{l}\text { Proportional } \\
\text { contribution }\end{array}$ & $\begin{array}{c}\text { Leaf } \\
\text { area } \\
\text { index }\end{array}$ & $\begin{array}{c}\text { Plant } \\
\text { height }\end{array}$ & $\begin{array}{c}\text { Days to } \\
50 \% \\
\text { flowering }\end{array}$ & $\begin{array}{c}\text { Panicles/ } \\
\text { plant }\end{array}$ & $\begin{array}{c}\text { Panicle } \\
\text { length }\end{array}$ & $\begin{array}{c}\text { Filled } \\
\text { grains/ } \\
\text { panicle }\end{array}$ & $\begin{array}{c}\text { Spikelet } \\
\text { sterility }\end{array}$ & $\begin{array}{c}\text { Harvest } \\
\text { index }\end{array}$ & $\begin{array}{c}1000 \\
\text { grain } \\
\text { weight }\end{array}$ & $\begin{array}{c}\text { Grain } \\
\text { yield/ } \\
\text { plant }\end{array}$ \\
\hline A lines & 7.88 & 55.62 & 33.01 & 10.15 & 43.03 & 10.63 & 8.51 & 3.74 & 30.13 & 14.61 \\
$\mathrm{R}$ lines & 13.57 & 17.82 & 48.12 & 26.40 & 9.57 & 20.53 & 57.79 & 49.76 & 55.79 & 33.99 \\
$\mathrm{~A} \times \mathrm{R}$ & 78.55 & 26.56 & 18.87 & 63.45 & 47.39 & 68.84 & 33.70 & 46.50 & 14.08 & 51.41 \\
\hline
\end{tabular}

Table 3. Estimates of general combining ability (GCA) effects of parents for different traits in rice

\begin{tabular}{|c|c|c|c|c|c|c|c|c|c|c|}
\hline Parents & $\begin{array}{c}\text { Leaf area } \\
\text { index }\end{array}$ & $\begin{array}{l}\text { Plant } \\
\text { height } \\
(\mathrm{cm})\end{array}$ & \begin{tabular}{|c|} 
Days to \\
$50 \%$ \\
flowering
\end{tabular} & $\begin{array}{c}\text { Panicles/ } \\
\text { plant }\end{array}$ & $\begin{array}{l}\text { Panicle } \\
\text { length } \\
(\mathrm{cm})\end{array}$ & $\begin{array}{c}\text { Filled } \\
\text { grains/pa } \\
\text { nicle }\end{array}$ & $\begin{array}{c}\text { Spikelet } \\
\text { sterility } \\
(\%)\end{array}$ & $\begin{array}{c}\text { Harvest } \\
\text { index }\end{array}$ & $\begin{array}{l}1000 \text { grain } \\
\text { weight }(g)\end{array}$ & $\begin{array}{c}\text { Grain yield/ } \\
\text { plant (g) }\end{array}$ \\
\hline \multicolumn{11}{|c|}{ A lines (5 Cytoplasmic Male Sterile lines) } \\
\hline Gan46A & -0.12 & -1.29 & $-3.40 * *$ & -0.32 & $-0.61 * *$ & $-6.47 * *$ & $3.12 * *$ & -0.005 & $0.53 *$ & $3.51 * *$ \\
\hline You1A & $0.44 * *$ & 0.86 & -0.36 & -0.15 & -0.22 & 3.63 & $-5.00 * *$ & 0.013 & $1.18 * *$ & $2.99 * *$ \\
\hline D ShanA & 0.28 & 0.02 & -0.15 & $-0.50 *$ & $-0.42 *$ & -3.59 & -1.14 & 0.008 & $1.11 * *$ & -0.47 \\
\hline IR58025A & -0.08 & $6.79 * *$ & $4.89 * *$ & $0.75 * *$ & $1.75 * *$ & $16.10 * *$ & $4.13 * *$ & $-0.032 * *$ & $-1.52 * *$ & $-4.59 * *$ \\
\hline $\mathrm{SE}(\mathrm{gi})$ & 0.15 & 0.705 & 0.356 & 0.201 & 0.189 & 2.244 & 1.027 & 0.011 & 0.21 & 0.671 \\
\hline SE (gi-gj) & 0.212 & 0.998 & 0.500 & 0.285 & 0.267 & 3.173 & 1.453 & 0.015 & 0.295 & 0.948 \\
\hline \multicolumn{11}{|c|}{ R lines (8 Restorer lines) } \\
\hline IR10198R & $-0.48 *$ & $-2.84 * *$ & $-2.42 * *$ & $1.01 * *$ & 0.11 & $-13.24 * *$ & 1.11 & 0.007 & $0.73 * *$ & 0.77 \\
\hline Gui99R & -0.10 & 0.84 & $1.78 * *$ & $0.75 * *$ & -0.15 & $8.32 * *$ & -4.47 & $0.031 *$ & -0.37 & 0.90 \\
\hline BR827R & 0.31 & $2.83 * *$ & $-0.89 *$ & $0.52 *$ & $-0.59 *$ & -0.45 & -1.73 & $0.050 * *$ & $0.82 * *$ & $5.55^{* *} *$ \\
\hline BR736R & $0.47 *$ & $-2.63 * *$ & $-6.63 * *$ & $-0.7 * *$ & $-0.57 *$ & $-6.09 *$ & $9.76 * *$ & $-0.119 * *$ & $-3.16 * *$ & $-8.18 * *$ \\
\hline BR168R & $-0.91 * *$ & $-2.94 * *$ & -0.69 & $-1.31 * *$ & 0.34 & $14.83 * *$ & $-8.03 * *$ & $0.086 * *$ & -0.10 & $4.03 * *$ \\
\hline SE (gi) & 0.189 & 0.892 & 0.450 & 0.255 & 0.239 & 2.838 & 1.300 & 0.014 & 0.264 & 0.848 \\
\hline SE (gi-gj) & 0.268 & 1.262 & 0.640 & 0.36 & 0.338 & 4.014 & 1.838 & 0.019 & 0.835 & 2.682 \\
\hline
\end{tabular}

Higher contributions of the testers to the total variance of crosses than that of the interactions of line $\mathrm{x}$ tester were recorded for days to $50 \%$ flowering, spikelet sterility and 1000 -grain weight. These observations however indicated the predominance of general combining ability for these traits. Similar results were also reported by Sarker (2001) for most of the morpho-agronomic traits in rice. On the other hand, higher contributions of the interactions (line $\times$ tester) to the total variances than that of either lines or testers in panicles/plant, panicle length, filled grains/panicle and grain yield/plant indicated the predominance of specific combining ability for those characters. Moreover, owing to high significant $(\mathrm{p}<.01)$ line $\mathrm{x}$ tester variance for all the traits (Table 1$)$, the performance of 
specific cross combinations were differently superior to others. This result is partially in agreement with the findings of Bashar (2002).

Table 4. Estimates of specific combining ability (SCA) effects of hybrids for different traits in rice

\begin{tabular}{|c|c|c|c|c|c|c|c|c|c|c|}
\hline Hybrid & $\begin{array}{l}\text { Leaf } \\
\text { area } \\
\text { index }\end{array}$ & $\begin{array}{l}\text { Plant } \\
\text { height } \\
(\mathrm{cm})\end{array}$ & \begin{tabular}{|c|} 
Days to \\
$50 \%$ \\
flowering
\end{tabular} & $\begin{array}{c}\text { Panicles/ } \\
\text { plant }\end{array}$ & $\begin{array}{c}\text { Panicle } \\
\text { length } \\
(\mathrm{cm})\end{array}$ & $\begin{array}{l}\text { Filled } \\
\text { grains/ } \\
\text { panicle }\end{array}$ & $\begin{array}{c}\text { Spikelet } \\
\text { sterility } \\
(\%)\end{array}$ & \begin{tabular}{|c|}
$\begin{array}{c}\text { Harvest } \\
\text { index }\end{array}$ \\
\end{tabular} & $\begin{array}{c}1000 \\
\text { grain } \\
\text { weight } \\
(\mathrm{g})\end{array}$ & $\begin{array}{c}\text { Grain } \\
\text { yield/ } \\
\text { plant (g) }\end{array}$ \\
\hline 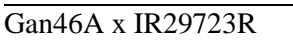 & $1.40 * *$ & $5.38 * *$ & $2.47 *$ & 0.06 & 0.33 & $-21.39 * *$ & $12.85^{* *}$ & $-0.076^{*}$ & -0.51 & $-8.47 * *$ \\
\hline Gan46A x IR46R & $2.32 * *$ & 0.92 & -0.87 & 0.94 & 0.38 & 11.96 & $-6.02 *$ & 0.026 & 0.52 & $6.96 * *$ \\
\hline Gan46A x IR34686R & $-2.69^{* *}$ & -0.96 & 1.33 & -0.23 & -0.56 & -4.09 & -3.41 & 0.033 & 0.23 & $3.79 *$ \\
\hline Gan46A x IR10198R & -0.07 & -0.91 & 0.47 & $-1.22 *$ & 0.46 & 7.03 & -4.68 & -0.014 & -0.25 & -1.35 \\
\hline Gan46A x Gui99R & $0.88 *$ & 1.35 & $-2.07 *$ & $1.34 *$ & $1.25 *$ & $39.07 * *$ & -3.79 & $0.07 *$ & -0.53 & $5.44 * *$ \\
\hline Gan46A x BR827R & $-0.96^{*}$ & -1.32 & -0.40 & -0.53 & -0.16 & 1.77 & -1.29 & 0.014 & $1.40 *$ & -1.67 \\
\hline Gan46A x BR736R & -0.35 & -0.72 & 0.00 & -0.58 & $-1.46^{* *}$ & $-48.65 * *$ & $6.57 *$ & $-0.092 * *$ & -1.14 & $-12.81 * *$ \\
\hline Gan46A x BR168R & -0.53 & -3.75 & -0.93 & 0.23 & -0.23 & $14.29 *$ & -0.24 & 0.039 & 0.28 & $8.10^{* *}$ \\
\hline You1A x IR29723R & -0.06 & 2.63 & -0.24 & $1.29 *$ & 0.31 & $32.65^{* *}$ & $-16.68 * *$ & $0.077 *$ & 0.31 & $8.16^{* *}$ \\
\hline You1A x IR46R & -0.11 & 0.17 & -0.91 & -0.16 & -0.77 & -0.80 & 3.46 & 0.009 & -0.89 & 3.70 \\
\hline You1A x IR34686R & -0.18 & 3.27 & $3.96 * *$ & 0.05 & $2.77 * *$ & $-25.35^{* *}$ & $10.69 * *$ & $-0.111 * *$ & $1.20 *$ & $-7.85^{* *}$ \\
\hline You1A x IR10198R & $1.12 * *$ & -2.66 & $-2.91 * *$ & -0.52 & -0.78 & $-13.13^{*}$ & 5.10 & 0.033 & 0.14 & -2.08 \\
\hline You1A x Gui99R & 0.09 & 1.36 & 0.22 & -0.93 & 0.31 & -11.69 & 4.16 & 0.003 & -0.76 & -1.80 \\
\hline You1A x BR827R & -0.38 & -0.60 & -0.11 & 0.64 & -0.85 & -2.39 & 1.37 & $-0.100 * *$ & 0.55 & $-7.70^{* * *}$ \\
\hline You1A x BR736R & $-0.84 *$ & -2.14 & 1.29 & -0.35 & -0.94 & $17.72 * *$ & $-6.27 *$ & $0.119 * *$ & 0.71 & $7.83 * *$ \\
\hline You1A x BR168R & 0.36 & -2.03 & -1.31 & 0.00 & -0.03 & 3.00 & -1.82 & -0.031 & $-1.25^{*}$ & -0.27 \\
\hline BRRI1A x IR29723R & -0.55 & -3.33 & $-2.62 * *$ & -0.90 & -0.26 & $-12.79 *$ & $8.99 * *$ & -0.019 & 0.04 & -2.84 \\
\hline BRRI1A x IR46R & -0.30 & 2.47 & 0.05 & 0.25 & $1.06^{*}$ & -8.97 & 3.65 & 0.045 & 0.02 & 1.91 \\
\hline BRRI1A x IR34686R & -0.02 & 1.53 & 0.92 & $-2.06^{* *}$ & -0.10 & 6.45 & -2.22 & -0.016 & -0.54 & 0.55 \\
\hline BRRI1A x IR10198R & 0.26 & -0.56 & $3.05 * *$ & $1.15^{*}$ & -0.89 & 3.76 & 4.51 & -0.035 & $1.94 * *$ & 0.03 \\
\hline BRRI1A x Gui99R & -0.25 & -0.70 & -1.82 & -0.22 & 0.41 & $22.87 * *$ & -4.19 & $0.083 * *$ & 0.07 & 1.06 \\
\hline BRRI1A x BR827R & 0.36 & 1.77 & 1.85 & -0.42 & $-1.07 *$ & $20.17 * *$ & -5.68 & 0.052 & -0.54 & $6.36 * *$ \\
\hline BRRI1A x BR736R & 0.10 & -3.57 & $-2.42 *$ & 0.93 & 0.90 & $-40.59 * *$ & -0.87 & $-0.148 * *$ & -0.64 & $-7.42 * *$ \\
\hline BRRI1A x BR168R & 0.40 & 2.40 & 0.98 & $1.27 *$ & -0.06 & 9.09 & -4.19 & 0.037 & -0.34 & 0.35 \\
\hline D ShanA x IR29723R & $-2.21 * *$ & -1.86 & -0.12 & 0.10 & -0.26 & $-20.2 * *$ & $11.51 * *$ & -0.057 & 0.68 & $-4.17 *$ \\
\hline D ShanA x IR46R & $-0.96^{*}$ & 1.87 & 0.22 & 0.65 & 0.25 & $12.752 *$ & -1.25 & -0.043 & -0.55 & $-7.47 * *$ \\
\hline D ShanA x IR34686R & $2.91 * *$ & 1.93 & 1.42 & $-1.92 * *$ & -0.79 & $20.84 * *$ & -3.84 & $0.072 *$ & -0.04 & $8.05 * *$ \\
\hline D ShanA x IR10198R & $-1.53^{* *}$ & -3.22 & $-2.45^{*}$ & 0.49 & -0.30 & 10.22 & $-6.56 *$ & 0.055 & -1.15 & $5.56 * *$ \\
\hline D Shan46A x Gui99R & 0.30 & 0.10 & $2.35 *$ & 0.08 & -0.12 & $-22.33 * *$ & -5.24 & $-0.083 * *$ & 0.58 & $-5.46^{* *}$ \\
\hline D ShanA x BR827R & $1.35^{* *}$ & 0.27 & -0.32 & $1.58 * *$ & -0.04 & 4.50 & 0.93 & 0.003 & -0.06 & 3.69 \\
\hline D ShanA x BR736R & -0.41 & -1.03 & -1.92 & -0.87 & $1.07 *$ & -11.06 & $6.29 *$ & 0.037 & 1.02 & 1.69 \\
\hline D ShanA x BR168R & 0.54 & 1.94 & 0.82 & -0.12 & 0.18 & 5.29 & -1.84 & 0.016 & -0.49 & -1.89 \\
\hline IR58025A x IR29723R & $1.42 * *$ & -2.82 & 0.51 & -0.55 & -0.11 & $21.74 * *$ & $-16.67 * *$ & $0.074 *$ & -0.52 & $7.32 * *$ \\
\hline IR58025A x IR46R & $-0.95^{*}$ & $-5.43^{* *}$ & 1.51 & $-1.68 * *$ & -0.91 & $-14.94 *$ & 0.17 & -0.037 & 0.90 & $-5.10 * *$ \\
\hline IR58025A x IR34686R & -0.02 & $-5.77 * *$ & $-7.63 * *$ & $4.16^{* *}$ & $-1.32 *$ & 2.15 & -1.21 & 0.022 & -0.84 & $-4.54 *$ \\
\hline IR58025A x IR10198R & 0.21 & $7.35^{* * *}$ & 1.84 & 0.10 & $1.51 * *$ & -7.87 & 1.62 & -0.040 & -0.68 & -2.17 \\
\hline IR58025A x Gui99R & $-1.02 *$ & -2.11 & 1.31 & -0.27 & $-1.84 * *$ & $-27.93 * *$ & $9.06 * *$ & $-0.072 *$ & 0.63 & 0.75 \\
\hline IR58025A x BR827R & -0.37 & -0.13 & -1.03 & $-1.27 *$ & $2.11 * *$ & $-24.06 * *$ & 4.67 & 0.031 & $-1.35^{*}$ & -0.68 \\
\hline IR58025A x BR736R & $1.50 * *$ & $7.47 * *$ & $3.04 * *$ & 0.88 & 0.43 & $82.58 * *$ & $-5.72 *$ & $0.084 * *$ & 0.05 & $10.71 * *$ \\
\hline IR58025A x BR168R & -0.77 & 1.44 & 0.44 & -1.38 & 0.14 & $-31.67 * *$ & $8.09 * *$ & $-0.062 *$ & $1.81 * *$ & $-6.29 * *$ \\
\hline$\overline{\mathrm{SE}}(\mathrm{Sij})$ & 0.423 & 1.995 & 1.006 & 0.57 & 0.534 & 6.347 & 2.906 & 0.03 & 0.59 & 1.896 \\
\hline SE (Sij-Ski) & 0.599 & 2.821 & 1.422 & 0.806 & 0.756 & 8.976 & 4.110 & 0.043 & 0.835 & 2.682 \\
\hline
\end{tabular}

$* \mathrm{p}<0.05, * * \mathrm{p}<0.01$

The estimates of GCA effects showed that none of the parent was general combiner for all the traits in desired direction (Table 3). However, Gan46A and BR827R were good general combiners for grain yield and earliness (i.e. days to $50 \%$ flowering) while, You1A, 
IR46R and BR168R were good general combiners for yield but poor combiner for earliness. IR58025A showed good GCA effect for panicles/plant, panicle length and filled grains/panicle but poor GCA effect for grain yield. It indicated that in spite of increasing effect of panicles/plant, filled grains/panicle and panicle length, decreasing effect of harvest index and 1000 grain weight and increasing effect of spikelet sterility (\%) finally led IR58025A to poor combining ability for grain yield. Wazuddin and Julfiquar (2002) also reported poor general combing ability of IR58025A for grain yield. However, Sarker et al. (2003) and Bashar (2002) reported IR58025A as good combiners for grain yield. Table 3 also showed that You1A, IR46R, IR34686R and BR168R were good general combiner for less sterility, while, Gan46A, You1A, D ShanA, IR29723R, IR34686R, IR10198R and BR827R were good general combiners for higher 1000-grain weight and IR46R, IR34686R, Gui99R and BR168R for filled grains/panicle. Furthermore, IR10198R, Gui99R and BR827R had significant positive GCA effect for panicles/plant. The above findings suggested that different yield components of the parents contributed to ultimate grain yield differently.

Specific combining ability effects varied from cross to cross (Table 4). Among the crosses Gan46AxGui99R was the best specific cross for earliness, longer panicle, panicles/plant, filled grains/panicle and grain yield. The similar finding was observed for panicles/plant, filled grains/panicle, lesser sterility and grain yield in You1AxIR29723R. The cross IR58025AxIR34686R attained significant SCA effect for earliness. IR58025AxIR46R appeared as the best specific combination for shorter plant height and longer panicle, while IR58025AxBR736R was observed as good specific cross for lateness, taller plant, greater number of filled grains/panicle, less sterility and higher grain yield. The crosses You1AxBR736R, D ShanAxIR346868R and IR58025AxIR29723R were found to be good specific combinations for higher number of filled grains/panicle, lesser sterility and higher grain yield. The above findings indicated that among the yield components, filled grains/panicle contributed mostly to be good specific crosses for higher grain yield. However, D ShanAxIR10198R was good specific combiner cross for earliness and higher grain yield without any influence of filled grains/panicle.

Furthermore, good specific crosses for grain yield were obtained from good $\mathrm{x}$ good (Gan46A x IR46R, Gan46A x BR168R), good x poor or poor x good (Gan46A x IR34686R, Gan46A x Gui99R, You1A x IR46R, You1A x BR736R, BRRI1A x BR736R) and poor $x$ poor (D ShanA x IR34686R, D ShanA x IR10198R, IR58025A x IR29723R and IR58025A $x$ BR736R) general combiner parents. These observations indicated that additive $x$ additive, additive $\mathrm{x}$ dominance and dominance $\mathrm{x}$ dominance gene interaction were responsible for derivation of good specific cross for higher grain yield.

\section{REFERENCES}

Anonymous. 2003. Adhunik Dhaner Chash. Bangladesh Rice Research Institute, Gazipur, Bangladesh. p60.

Bashar, M. K. 2002. Genetic and morphological basis of heterosis in rice (Oryza sativa). $\mathrm{Ph} . \mathrm{D}$ Thesis in Genetics and Plant Breeding. BSMRAU, Gazipur.

Bobby, T. P. M. and Nadarajan, N. 1993. Genetic analysis of yield components in rice involving CMS lines. IRRN. 18(1): 8-9.

Kempthrone, O. 1957. An introduction to genetic statistics. New York: John Wiley and Sons, Inc. London: Chapman \& Hall, Ltd. 
Kwak, T. S. 1999. Combining ability of harvest index, productivity score and related charecters in $F_{1}$ hybrid of indica and Tongil-type rice. Korean J. Breed. 31(1): 35-39.

Liao, FuMing, KunLu Zhou, HeHua Yang, QiuSheng Xu, HeLong Ping, F. M. Liao, K. L. Zhou, H. H. Yang, Q. S. Xu and H. P. Long. 2000. Combining ability and heritability of grain quality characters in indica hybrid rice. Journal Hunan Agricultural University. 26(5):323-328.

Lang, N. T. \& B. C. Buu. 1993. Combining ability and heterosis for some physiological traits in rice. IRRN. 18(1): 7-8.

Rogbell, J. E. and N. Subbaraman. 1997. Line x tester analysis for combining ability in saline rice cultivars. Madras Agril. J. 84(1): 22-25.

Salam, M.A., M.A. Hossain and S. Khatun. 1996. Combining ability for grain yield and its components in rice. Ann. Bangladesh Agric. 6(1):21-26.

Sarker, U. 2001. Combining ability of CMS and restorer lines in rice (Oryza sativa L). MS Thesis. BMSRAU, Salna, Gazipur. Bangladesh. 96p.

Sarker, U., M. G Rasul and M. A. K. Mian. 2003. Combining ability of CMS and restorer lines in rice (Oryza sativa L). Bangladesh J. Pl. Breed. Gent., 16(1): 01-07.

Sunohara, Y., M. Yajima, M. Suzuki and H. Seiki. 1985. Dry matter production of $F_{1}$ rice hybrids. Heterosis in initial growth and sink size. Jpn. J. Crop. Sci. 54 (1): 132-133.

Virmani, S. S., and I.B. Edwards. 1983. Current status and future prospects for breeding hybrid rice and wheat. Adv. Agron. 36: 145-214.

Wazuddin, M. and A. W. Julfiquar. 2002. Initiative towards development of parental materials for hybrid rice. In Hybrid Rice in Bangladesh: Progress and Future Strategies. Proceedings of the First National Workshop on Research and Development of Hybrid Rice in Bangladesh. Bangladesh Rice Research Institute, Gazipur. 